\title{
Chemical Control of Cowpea Powdery Mildew and Foliar Spots ${ }^{1}$
}

\author{
Rocio Rodriguez and P. L. Meléndez ${ }^{2}$
}

\begin{abstract}
The fungicides chlorothalonil, mancozeb, dinocap, benomyl and Macuprax controlled foliar diseases of cowpea, such as powdery mildew (Erysiphe polygoni DC) and leaf spots (Corynespora cassiicola (Berk. \& Curt.) Wei, and Cercospora spp.). Dinocap was very effective against powdery mildew during the dry season, but failed to protect the plants during rainy weather. Low dosages ( $0.28 \mathrm{~kg} / \mathrm{ha})$ of benomyl applied biweekly were enough to prevent infection by $\boldsymbol{E}$. polygoni, C. cassiicola and Cercospora spp. It is suspected that a new race of $E$. polygoni, capable of thriving under high relative humidity and heavy rains, is present in the field. In addition, the erratic performance of benomyl in controlling powdery mildew suggests the existence of field races of the pathogen resistant to this fungicide.
\end{abstract}

\section{INTRODUCTION}

Cowpeas [Vigna unguiculata (L.) Walp.], are an important food supply in some areas of the world. The green pods, leaves and dry peas, represent a good source of vitamins, minerals and protein. Aluma (1) reported that cowpeas contain $88.2-148.5 \mathrm{mg}$ of vitamin C/100 g. Sheets (10) found that dried cowpeas were effective in upgrading hemoglobin levels to the normal range. The studies of Halverston and Sherwood (5) showed that, although cowpeas do not contain appreciable quantities of vitamin A they can be regarded as an excellent source of vitamin B1. Moreover, Levy et al. (7) emphasized the use of cowpea leaves in the diet of the South African natives. Duke (4) showed that the green seed, ripe seed, seed and shoots contain 27.1, 25.5, 25.7, and 43.6 grams of protein, respectively.

Although cowpeas are not a principal staple in our daily diet, those consumed in Puerto Rico are imported. However, the demand for this legume can be supplied by the Puerto Rican grower if he applies the technology necessary to increase yield and to obtain high quality produce.

Our tropical conditions (humidity and temperature) provide the ideal environment for disease development. The most common diseases of cowpeas in the island are powdery mildew, caused by Erysiphe polygoni DC, and foliar spots, caused by Cercospora cruenta Sacc., Cercospora canescens Ellis \& Martin and Corynespora cassiicola (Berk. \& Curt.) Wei.

Under the sponsorship of the Project for the Improvement of Tropical

${ }^{1}$ Manuscript submitted to Editorial Board, November 301983.

${ }^{2}$ Research Assistant and Phytopathologist, Department of Crop Protection, College of Agricultural Sciences, University of Puerto Rico, Mayagüez, P. R. Mr. Gerardo Mangual Crespo managed the field trials. 
Production of Beans and Cowpeas through Disease and Insect Control, experiments were conducted to evaluate the effectiveness of several fungicides to control these diseases under field conditions. The results of these findings are presented herein.

\section{MATERIALS AND METHODS}

\section{POWDERY MILDEW}

Five field trials were conducted at the Isabela Research and Development Center in October 1973, January 1974, August 1974, February 1975 and February 1976, to test the efficacy of dinocap, chlorothalonil, benomyl, mancozeb and Macuprax on the control of this disease. The chemicals were tested at three different dosages: mancozeb, chlorathalonil and Macuprax at 1.12, 2.24 and $4.48 \mathrm{~kg} / \mathrm{ha}$; and dinocap and benomyl at 0.28 , 0.60 and $1.12 \mathrm{~kg} / \mathrm{ha}$. Except for benomyl, which was applied biweekly, all others were applied on a weekly basis. Applications were directed to the foliage of susceptible cowpea cv. Early Ramshorn with a knapsack sprayer. Ten treatments replicated five times were arranged in a paired plot design. Each experiment covered an area of 0.08 ha with plots of 14 $\mathrm{m}^{2}$ and three rows of plants per plot. Fertilizer 10-10-8 at the rate of 2.24 $\mathrm{kg} / \mathrm{ha}$ per row was applied at planting time. Weeds were controlled with $3.36 \mathrm{~kg} / \mathrm{ha}$ of Dacthal $75 \mathrm{~W}$ before emergence and handweeded until harvest. Periodic applications of Diazinon AG-500 prevented insect damage. To determine the efficacy of the pesticides, yield and disease index, based on general appearance of plants in the central row, were recorded. Disease ratings, based on percentage of foliage affected, were recorded on a 0 to 5 scale, in which, $0=$ no disease, $1=1-20 \%, 2=21-40 \%, 3=$ $41-68 \%$ and $5=81-100 \%$. On the basis of Sherwood and Hagedorn (11), disease indices were calculated by means of the following equation:

$$
\mathrm{DI}=\frac{\sum(\text { disease class } \times \text { number of plants in that class })}{\text { Total number of plants } \times \text { highest disease class }} \times 100
$$

Differences between treatments were subjected to analysis of variance and the means compared with the $t$ test, and orthogonal comparisons.

\section{LEAF SPOTS}

A trial was conducted September 1973 to evaluate the fungicides mancozeb, benomyl and chlorothalonil in the control of Cercospora spp. and Corynespora cassiicola on cowpea. Experiment size, design, fungicide dosages as well as agronomic practices were similar to those applied in the aforementioned trials for the control of powdery mildew. Yield and number of spots per plant caused by these pathogens were recorded from 
the same experiment since symptoms of the two diseases are easily distinguishable from each other.

\section{RESULTS AND DISCUSSION}

\section{POWDERY MILDEW}

Table 1A, B, C, D, and E summarized data from five experiments on chemical control of cowpea mildew. Table $1 \mathrm{~A}$ shows that in the first experiment all fungicides tested achieved good control. Yields from most fungicide-treated plots were significantly higher than those from check plots.

In the second experiment (table 1B), infection by the powdery mildew causal organism was most severe. The check plants were damaged to such an extent that they were almost completely defoliated. Yields from plots treated with benomyl at $0.60 \mathrm{~kg}$, and mancozeb at 2.24 and $4.48 \mathrm{~kg} /$ ha were significantly higher than yields from control plots. Yields of the $0.60 \mathrm{~kg}$ benomyl-treated plots were almost four times higher than those from control plots.

In the third experiment, regardless of the heavy rain which prevailed throughout the growing season, the plants were severely attacked by the mildew pathogen and total defoliation occurred in the check plots. (table 1C).

On the basis of the disease index recorded for each fungicide (table $1 \mathrm{C})$, benomyl and mancozeb effectively controlled the disease, but dinocap, which had proved to be very effective under drier conditions, failed in this test to protect the plants. Since mildew attack took place after most of the pods were already developed, the check plots yielded as much as most of the fungicide-treated plots, regardless of the extent of defoliation. The increased yields obtained in this trial irrespective of treatments may be attributed to higher soil fertility of the experimental site.

Mildew attack is usually checked by abundant rain, but this was not so in this instance. This unexpected phenomenon suggests that a race of the pathogen capable of thriving under high relative humidity has developed in the field. Moreover, as mentioned earlier, the fungicide dinocap failed to protect the plants, regardless of the concentration used. Therefore, if a new race has developed it appears to be resistant to dinocap.

In the fourth experiment (table 1D) both Macuprax and mancozeb at the rates of $1.12,2.24$ and $4.48 \mathrm{~kg} / \mathrm{ha}$, effectively protected the foliage of cowpea plants against the mildew organism (fig. 1). This protection is evidenced by the low disease indices and the high yields recorded from treated plots. Coincidentally, yields from plots treated with Macuprax at the rate of $2.24 \mathrm{~kg} /$ ha were almost twice as large as those from nonsprayed plots. 
TABLE 1.-Disease index and yield of cowpea cu. Early Ramshorn treated with fungicides to control powdery mildew

\begin{tabular}{|c|c|c|c|}
\hline Treatments & $\begin{array}{l}\text { Rate } \\
\mathrm{kg} / \mathrm{ha}\end{array}$ & $\begin{array}{l}\text { Disease } \\
\text { Index }\end{array}$ & $\begin{array}{l}\text { Yield } \\
\mathrm{kg} / \mathrm{ha}\end{array}$ \\
\hline \multicolumn{4}{|c|}{ A. October 1973} \\
\hline Mancozeb & 1.12 & $28^{* * 1}$ & 296 \\
\hline Mancozeb & 2.24 & $16^{* *}$ & $551^{* 2}$ \\
\hline Mancozeb & 4.48 & $16^{* *}$ & $525^{*}$ \\
\hline Benomyl & 0.28 & $0^{* *}$ & 403 \\
\hline Benomyl & 0.60 & $0^{* *}$ & $652^{* *}$ \\
\hline Benomyl & 1.12 & $0^{* *}$ & $533^{*}$ \\
\hline Chlorothalonil & 1.12 & $32^{*}$ & $529^{*}$ \\
\hline Chlorothalonil & 2.24 & $20^{* *}$ & $367^{*}$ \\
\hline Chlorothalonil & 4.48 & $16^{* *}$ & $482^{*}$ \\
\hline Check & & 80 & 185 \\
\hline \multicolumn{4}{|c|}{ B. January 1974} \\
\hline Dinocap & 0.28 & & 312 \\
\hline Dinocap & 0.60 & & 365 \\
\hline Dinocap & 1.12 & & 355 \\
\hline Benomyl & 0.28 & & 376 \\
\hline Benomyl & 0.60 & & $665^{* * *}$ \\
\hline Benomyl & 1.12 & & 333 \\
\hline Mancozeb & 1.12 & & 281 \\
\hline Mancozeb & 2.24 & & $461^{*}$ \\
\hline Mancozeb & 4.48 & & $406^{*}$ \\
\hline Check & & & 195 \\
\hline \multicolumn{4}{|c|}{ C. August 1974} \\
\hline Dinocap & 0.28 & 88 & $1610^{3}$ \\
\hline Dinocap & 0.60 & 84 & 1419 \\
\hline Dinocap & 1.12 & 76 & 1448 \\
\hline Benomyl & 0.28 & $12^{* *}$ & 1634 \\
\hline Benomyl & 0.60 & $8^{* *}$ & 1882 \\
\hline Benomyl & 1.12 & $4^{* *}$ & 1970 \\
\hline Mancozeb & 1.12 & $40^{*}$ & 1938 \\
\hline Mancozeb & 2.24 & $20^{*}$ & 2035 \\
\hline Mancozeb & 4.48 & $0^{* *}$ & 2137 \\
\hline Check & & 100 & 1642 \\
\hline \multicolumn{4}{|c|}{ D. February 1975} \\
\hline Macuprax & 1.12 & $46^{* *}$ & 1283 \\
\hline Macuprax & 2.24 & $26^{* *}$ & $1701^{* *}$ \\
\hline Macuprax & 4.48 & $22^{* *}$ & $1418^{*}$ \\
\hline Benomyl & 0.28 & 78 & 1106 \\
\hline Benomyl & 0.60 & 74 & 1051 \\
\hline Benomyl & 1.12 & 70 & 1222 \\
\hline Mancozeb & 1.12 & $30^{* *}$ & $1482^{*}$ \\
\hline Mancozeb & 2.24 & $30^{* *}$ & 1350 \\
\hline Mancozeb & 4.48 & $24^{* *}$ & $1504^{* *}$ \\
\hline Check & & 92 & 1068 \\
\hline
\end{tabular}


Table 1-Continued

\begin{tabular}{lrrr} 
& \multicolumn{2}{c}{ E. February 1976} & \\
Dinocap & 0.28 & $20^{* *}$ & $2693^{3}$ \\
Dinocap & 0.60 & $24^{* *}$ & 2616 \\
Dinocap & 1.12 & $8^{* *}$ & 2495 \\
Chlorothalonil & 1.12 & $24^{* *}$ & 2539 \\
Chlorothalonil & 2.24 & $24^{* *}$ & 2604 \\
Chlorothalonil & 4.48 & $8^{* *}$ & 2466 \\
Benomyl & 0.28 & $52^{* *}$ & 2466 \\
Benomyl & 0.60 & $40^{* *}$ & 2792 \\
Benomyl & 1.12 & $32^{* *}$ & 2782 \\
Check & & 100 & 2315 \\
\hline
\end{tabular}

${ }^{1}$ Significantly different from the check at $\mathrm{P}=0.01$.

${ }^{2}$ Significantly different from the check at $\mathrm{P}=0.05$.

${ }^{3}$ Significant differences between treatments and the check were not detected.

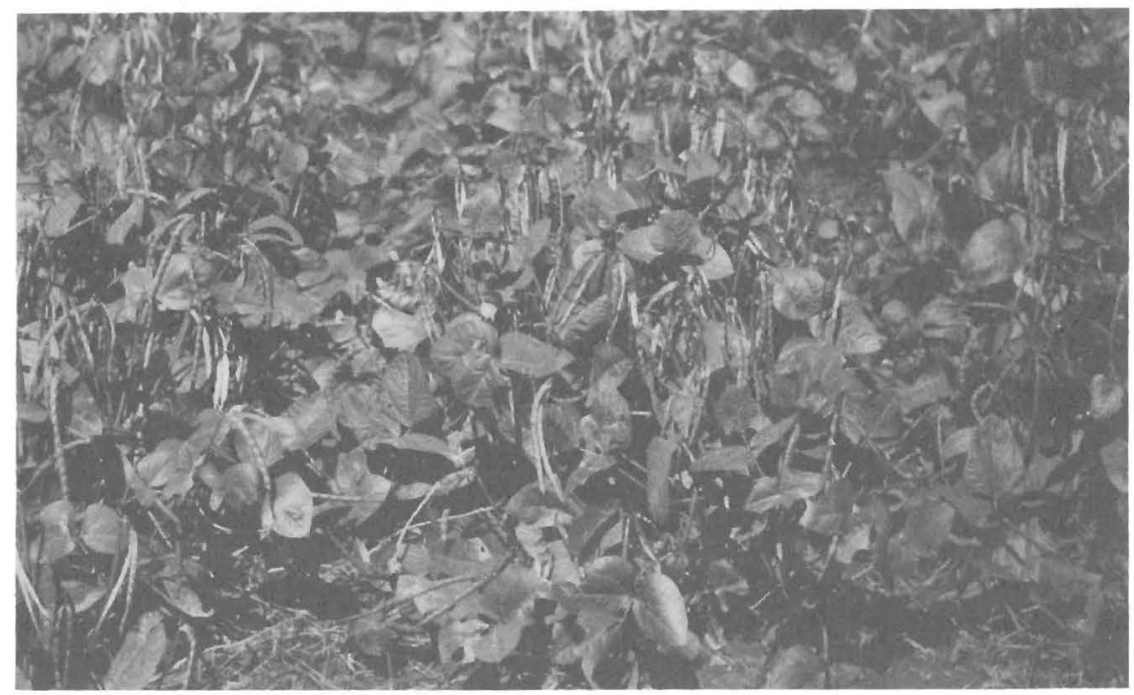

FIG. 1.-Treatment with mancozeb at the higher rate tested, $4.48 \mathrm{~kg} / \mathrm{ha}$. Experiment conducted in February 1976

In the 1976 trial (table 1E), although weather conditions were ideal for powdery mildew infection, invasion did not occur until the beginning of pod set. Therefore, even when the non-sprayed plots became completely defoliated (fig. 2), yields from these plots were as high as those from the fungicide-treated plots. Table $1 \mathrm{E}$ shows that all fungicides tested protected the cowpea foliage effectively against mildew attack. Even benomyl, which failed to provide protection against the disease in the 1975 
trial, was effective at all dosages tested. However, on the basis of the disease index, there is still a great reduction in the effectiveness of this fungicide in controlling mildew if compared to its effectiveness in the 1973 and 1974 trials (table $1 \mathrm{~A}$ and C).

In general the analyses of variance of disease index and yield for all trials (table 2) showed significant differences among overall treatments means, and between fungicide treatments and the check. Two nonsignificant exceptions occurred; the effect of treatments on yield in October 1973, and the comparison of treated vs. check on yield in August 1974. The effectiveness of fungicides and their concentrations vary as indicated by significant differences among these treatments in diesase incidence

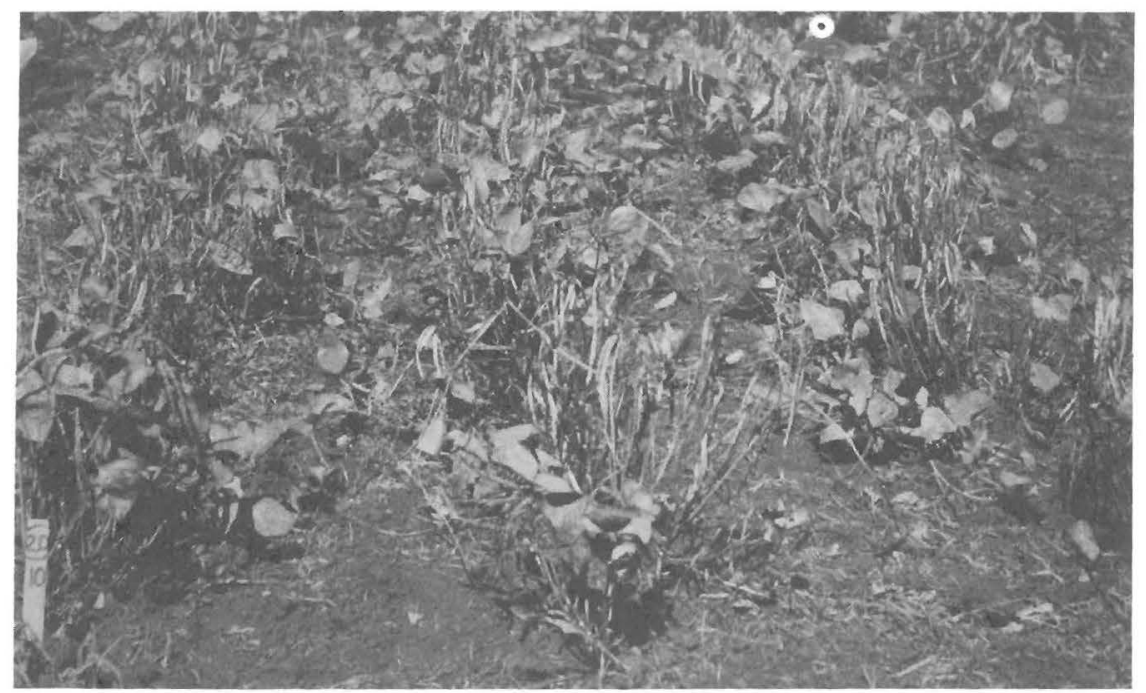

FIG. 2.-Defoliation caused by the disease in the non-treated plots. Notice the abundance of pods. Infection occurred after pod setting.

reduction and yield increase. Except for the August 1974 trial, interactions between fungicides and concentrations were found. This indicates that the response in disease reduction and yield increment to different fungicides depended on the concentration level of the fungicide. In most trials, reduction in disease incidence with increased concentrations was significantly linear. This linear response was not of the same magnitude and direction for all fungicides as evidenced by the interaction mentioned above. Depending on the fungicide, both positive and negative linear responses in yield occurred with an increase in concentration (tables 1AE). For disease index the linear effect of concentration was always negative but varied in magnitude from one fungicide to another. 
TABLE 2.-F values for significant disease index and yield in five trials on the control of cowpea powdery mildew using Orthogonal comparisons

\begin{tabular}{|c|c|c|c|c|c|c|c|c|}
\hline \multirow{2}{*}{$\begin{array}{l}\text { Source of } \\
\text { variation }\end{array}$} & \multicolumn{8}{|c|}{$F$ values } \\
\hline & DI & Yield & $\frac{\text { January } 1974}{\text { Yield }}$ & DI & Yield & DI & Yield & $\frac{\text { February } 1976}{\text { DI }}$ \\
\hline Treatments (adjusted) & $63.27^{* * 2}$ & 2.13 & $10.69^{* *}$ & $28.18^{* *}$ & $3.65^{*}$ & $52.82^{* *}$ & $13.40^{* *}$ & $21.70^{* *}$ \\
\hline Fungicides & $31.91^{* *}$ & 1.33 & $5.27^{* *}$ & $79.54^{* *}$ & $15.64^{* *}$ & $159.91^{* *}$ & $4.36^{* *}$ & $18.14^{* *}$ \\
\hline Concentrations & $10.26^{* *}$ & $6.32^{* *}$ & $12.97^{* * *}$ & $5.06^{* *}$ & 0.81 & $9.17^{* *}$ & $13.24^{* *}$ & $75.40^{* *}$ \\
\hline Fung. $\times$ Conc. & 2.68 & $4.01^{*}$ & $4.49^{* * *}$ & 2.52 & 1.35 & $9.96^{* *}$ & $5.54^{* *}$ & $3.33^{*}$ \\
\hline Check v. Treated & $310.45^{* *}$ & $21.03^{* *}$ & $18.93^{* *}$ & $61.46^{* *}$ & 1.28 & $197.47^{* *}$ & $14.64^{* *}$ & $189.00^{* *}$ \\
\hline Variance for Error: & 0.1053 & 4223.47 & 2135.65 & 0.6967 & 64861.06 & 0.1675 & 5335.69 & 0.42 \\
\hline
\end{tabular}


Significant linear effects of concentration occur for disease index only and not for yield. This fact suggests that reductions of disease incidence due to increased concentrations are not associated with an increase in yield. The response in yield for each fungicide varies according to concentration (evidenced by the significant interaction) but low concentration of most fungicides should provide enough control for practical purposes. Some significant quadratic effects of concentrations were found for yield and disease index.

Arif and Goode (2) and Roy (8), found that benomyl used either as foliar spray or as a soil drench, protected cowpeas effectively against mildew. Singh and Naik (15), Singh and Mishra (12), and Srivastava et al. (16) reported similar results with foliar applications of dinocap to control powdery mildew on peas. However, the data collected throughout our trials strongly suggest the presence in the field of races of this pathogen resistant or tolerant to some fungicides. It has been reported that the continuous use of benomyl induces the pathogen to mutate producing races which are resistant or tolerant to the action of the chemical. Dekker and Davidse (3) reported that since the introduction of benomyl for the control of plant diseases, development of fungi resistance to this fungicide has been observed frequently. In several cases, tolerance was evident shortly after application. Furthermore, Schroeder and Provvidenti (9) observed a decreasing effectiveness of benomyl against cucumber powdery mildew. Our experience, added to that of other researchers, indicates that pesticide users must be more cautious in the field while using those chemicals which seem likely to stimulate resistance.

\section{LEAF SPOTS}

Data on leaf spot of cowpea caused by Cercospora spp. and Corynespora cassiicola is shown in table 3. Apparently, inoculum potential of $C$. cassiicola was greater than that of Cercospora spp. as evidenced by the number of spots caused by this pathogen on the host plants. However, the number of spots caused by each fungus on the nontreated controls was significantly greater than that recorded from most of the fungicidetreated plots. Therefore, all fungicides tested effectively controlled leaf spots. According to the data collected the best fungicide for the control of leaf spots is benomyl, since dosages of this chemical as low as $0.28 \mathrm{~kg} /$ ha were very effective. Yields from plots treated with chlorothalonil at $4.48 \mathrm{~kg} / \mathrm{ha}$ and benomyl at 0.60 were significantly greater than those from the non-treated checks.

Significant differences between the overall mean of treatments and the check for number of target spots were detected (table 4). Conversely no significant differences for spots caused by Cercospora spp. were shown. 
TABLE 3.- Yield of cowpea cu. Early Ramshorn after exposure to various fungicidal treatments to control leaf spot ${ }^{1}$

\begin{tabular}{lcccc}
\hline \multicolumn{1}{c}{ Treatments } & \multicolumn{3}{c}{ Rate } \\
$\mathrm{kg} / \mathrm{ha}$ & \multicolumn{2}{c}{$\begin{array}{c}\text { No. of spots } \\
\text { per plant } \\
\text { Corynespora }\end{array}$} & $\begin{array}{c}\text { Yield } \\
\mathrm{kg} / \mathrm{ha}\end{array}$ \\
\hline Mancozeb & 1.12 & $47^{* * 2}$ & 15 & 1536 \\
Mancozeb & 2.24 & $26^{* *}$ & $6^{* 3}$ & 1583 \\
Mancozeb & 4.48 & $13^{* *}$ & $3^{*}$ & 1386 \\
Benomyl & 0.28 & $10^{* *}$ & $0^{* *}$ & 1344 \\
Benomyl & 0.60 & $32^{* *}$ & $2^{* * *}$ & 1526 \\
Benomyl & 1.12 & $17^{* *}$ & $1^{* *}$ & $2048^{* *}$ \\
Chlorothalonil & 1.12 & $142^{* *}$ & 55 & 1682 \\
Chlorothalonil & 2.24 & $62^{* *}$ & $3^{* *}$ & 1608 \\
Chlorothalonil & 4.48 & $139^{* *}$ & $5^{*}$ & $1838^{*}$ \\
Check & & 234 & 56 & 1076 \\
\hline
\end{tabular}

${ }^{1}$ Total of five replications.

${ }^{2}$ Significantly different from the check at $\mathrm{P}=0.01$.

${ }^{3}$ Significantly different from the check at $\mathrm{P}=0.05$.

TABLE 4.-F values for disease index and yield in trial for the chemical control of foliar spots on cowpea using Orthogonal comparisons

\begin{tabular}{lccc}
\hline \multirow{2}{*}{$\begin{array}{c}\text { Source of } \\
\text { variation }\end{array}$} & \multicolumn{3}{c}{$F$ values } \\
\cline { 2 - 3 } & \multicolumn{2}{c}{ No. spots } & Yield \\
\cline { 2 - 3 } & C. cassiicola & Cercospora sp. & 1.07 \\
\hline Blocks & 1.78 & 0.80 & $2.79^{* 2}$ \\
Treatments & $12.84^{* * 1}$ & 1.95 & 2.05 \\
Fungicides & $21.2^{* *}$ & $4.34^{*}$ & 2.84 \\
Concentrations & $5.0^{*}$ & $5.32^{*}$ & $5.14^{*}$ \\
$\quad$ Linear & $9.67^{* *}$ & $9.60^{* *}$ & 0.55 \\
Quadratic & 0.35 & 1.05 & $3.40^{*}$ \\
Fung. $\times$ Conc. & 2.57 & 0.69 & 2.57 \\
Check v. Treated & $67.69^{* *}$ & 2.70 & 18310.9375 \\
Variance for Error & 87.2375 & 30.3050 & \\
\hline
\end{tabular}

${ }^{1}$ Significantly different at $\mathrm{P}=0.01$.

${ }^{2}$ Significantly different at $\mathrm{P}=0.05$.

This indicates that differences detected in yield (table 3) are probably due to the effect of treatments on the control of $C$. cassiicola. Linear reduction in number of spots and yield increment with increased concentrations was obtained. No significant differences in yield among fungicides and concentrations were detected. However, the interaction of these two factors was significant, indicating that the response in yield with the application of fungicides depends on concentration. High concentrations of some fungicides are needed while low concentrations suffice for others. 
Singh and Mishra (13) and Jones (6) revealed that benomyl controlled C. cruenta on Phaseolus aureus Roxb., and C. cassiicola on cucumber. However, in contrast with our results, Singh and Singh (14) found that mancozeb was not effective in controlling $C$. canescens on Phaseolus aureus Roxb.

Control by benomyl is considered of great significance because, besides increasing yields, both the number of applications and the concentrations are lower than those of most of the other chemicals evaluated. Nevertheless, in view of the resistance phenomenon, with the continued use of this fungicide, combination with other chemicals is advisable because mixing might reduce the development of resistance.

\section{RESUMEN}

Los fungicidas chlorothalonil, mancozeb, dinocap, benomyl y Macuprax combatieron eficazmente las enfermedades foliares del frijol de costa (Vigna unguiculata (L.) Walp) en Isabela, Puerto Rico. Las enfermedades foliares controladas fueron anũblo pulverulento (Erysiphe polygoni DC) y manchas foliares causadas por Corynespora cassiicola (Berk. \& Curt.) Wei y Cercospora spp. El dinocap controló muy eficazmente el añublo pulverulento durante la sequia, pero no protegió las plantas en la época lluviosa. Las dosis bajas de benomyl $(0.28 \mathrm{~kg} / \mathrm{ha})$, aplicadas cada 14 días, protegieron muy eficazmente el follaje del frijol contra el ataque de estos patógenos foliares.

En los ensayos de combate químico del añublo pulverulento se obtuvieron aumentos en producción de más de $50 \%$ sobre el testigo con aplicaciones semanales de 2.24 y $4.48 \mathrm{~kg} / \mathrm{ha}$ de Macuprax y mancozeb, respectivamente. Durante los diferentes ensayos, el benomyl se comportó erráticamente en el control de esta enfermedad, lo que sugiere la presencia en el campo de razas fisiológicas resistentes al fungicida. Igualmente el ataque por este patógeno durante la época de lluvia indica la posible presencia de razas patogénicas de este hongo capaces de sobrevivir bajo condiciones de lluvia y alta humedad relativa.

\section{LITERATURE CITED}

1. Aluma, R. C., 1946. Cheap sources of vitamin C. Rev. Colomb. Quim. 2 (2): 30-1. (Abst. 0046). International Grain Legume Information Center IITA Vol. II.

2. Arif, A. and Goode, M. J., 1970. Systemic chemical control of cowpea powdery mildew. Plant Dis. Rep. 54 (4): 346.

3. Dekker, J. and Davidse, L.C., 1975. Acquired resistance to benzimidazole derivatives. Environmental Quality and Safety. Suppl. Vol. III. Pesticides Lectures held at the IUPAC Third International Congress of Pesticides Chemistry, Helsinki, 3-9 July 1974. George Thieme, Publishers, Stuttgart.

4. Duke, J. A., 1981. Handbook of Legumes of World Economic Importance, Plenum Press, New York. 
5. Halverston, J. O. and Sherwood F.W., 1940. The vitamin A activity and vitamin E1 content of soybeans and cowpeas, J. Agric. Res, 60: 141.

6. Jones, J. P., 1974. Fungicides for the control of target leaf spot, soil rot and powdery mildew of cucumber, Plant Dis. Rep. 58 (7); 636.

7. Levy, L. F., Wintroub D., and Fox F. W., 1936. The food value of some common edible leaves, S. Afr. Med. J. 10:699. (Abst. 1151). International Grain Legume Information Center. IITA. Vol. III.

8. Roy, A. K., 1973. Occurrence and control of powdery mildews on a few plants in Assam, Indian Phytopath. 26 (3): 578.

9. Schroeder, W. T. and Provvindenti, R., 1969. Resistance to benomyl in powdery mildew of cucurbits, Plant Dis. Rep. 53:271.

10. Sheets, O., 1932. The effect of feeding green leafy vegetables and cowpeas in nutritional anemia, J. Home Econ. 24: 928.

11. Sherwood, R. T. and Hagedorn, D. J., 1958. Determining the common root rot potential of pea fields, Agric. Exp. Stn. Univ. Wis. Bull. 531.

12. Singh, D. V. and Mishra, A. N., 1976. Control of powdery mildew of pea with fungicides, Indian Phytopath. 29: 337.

13. - - and - - 1976. Control of powdery mildew of pea with fungicides, Indian Phytopath. 28 (3): 414.

14. - - and Singh, R. R., 1976. Chemical control of Cercospora leaf spot of green-gram, Indian Phytopath. 29: 337.

15. Singh, S. D. and Naik, S. M. P., 1977. Evaluation of some fungicides for the control of powdery mildew of pea, Indian J. Agri. Sci. 47 (2): 87.

16. Srivastava, U. S., Agrawat, J. M. and Rai, R. A., 1973. Chemical control of powdery mildew (Erysiphe polygoni) on pea, Indian Phytopath. 26 (3); 537. 